\title{
TESTING PLANT PHENOPHASE AS PROXY: SENSITIVITY ANALYSIS OF FIRST FLOWERING DATA FROM THE $19^{\mathrm{TH}}$ CENTURY
}

\author{
LEHOCZKY, A. ${ }^{1}{ }^{*}$-SZABÓ, B. ${ }^{2}-$ PONGRÁCZ, R. ${ }^{3}-$ SZENTKIRÁLYI, F. ${ }^{4}$ \\ ${ }^{I}$ Centre for Climate Change, Campus de les Terres de l'Ebre, Geography Department, \\ University Rovira i Virgili \\ Tortosa 43500, Avinguda Remolins, 13-15, Spain \\ (phone: +34-977-464048; fax: +34-977-464025) \\ ${ }^{2}$ Department of Plant Systematics, Ecology and Theoretical Biology, Institute of Biology, \\ Eötvös Loránd University \\ H-1117, Budapest, Pázmány Péter sétány 1/C, Hungary \\ ${ }^{3}$ Department of Meteorology, Institute of Geography and Earth Sciences, \\ Eötvös Loránd University \\ H-1117, Budapest, Pázmány Péter sétány 1/A, Hungary \\ ${ }^{4}$ Plant Protection Institute, Centre for Agricultural Research, Hungarian Academy of Sciences \\ H-1022, Budapest, Hermann Otto street 15, Hungary \\ *Corresponding author \\ e-mail: annamaria.lehoczky@urv.cat \\ (Received 23 ${ }^{\text {rd }}$ Mar 2015; accepted $10^{\text {th }}$ Feb 2016)
}

\begin{abstract}
Eco-climatological studies recognise plant phenophases as high-confident climate indicators, since they are strongly dependent on heat conditions. We investigated the first flowering response of numerous plant species to inter-annual fluctuation of seasonal temperatures (e.g., heat sensitivity of the phenophase), also the rate of these species-specific sensitivities in order to test their applicability as proxy. From the few available data sources recorded in the Carpathian Basin during the 19th century, the first flowering data sets of 16 plant species and time series of monthly mean temperature (site: Hermannstadt; period: 1851-1891), furthermore the North Atlantic Oscillation (NAO) were selected for the analysis. We found that the first flowering dates of different plants fluctuated significantly synchronously, however, temporal trends were not detected in any of the time series. Based on the main heat sensitivity characteristics the species were ranked as phyto-thermometers to select the best heat indicator plants. The first flowering data of these indicators were applicable to estimate temperature data. The accuracy of different plants as proxies varied in the range of $1.0^{\circ} \mathrm{C}$ and $1.5{ }^{\circ} \mathrm{C}$. Therefore our procedure is of interest in order to better understand past climates of periods at locations where no instrumental records are available.
\end{abstract}

Keywords: flowering onset, effective temperature, moving window technique, heat sensitivity, proxy

\section{Introduction}

The Earth is already experiencing human induced global scale climatic changes, which affect the whole biosphere. Evidences are increasing according to the biological responses documented (Walther et al., 2002; Parmesan and Yohe, 2003; Root et al., 2003; Bartholy et al., 2012) in plant and animal populations. The most easily detectable and widely reported changes can be worldwide seen in the timing of phenological events (Miller-Rushing and Primack, 2008). Several study have been gathered from the past half-century about spatial and temporal shifts of plant phenophases associated with 
global warming trends. Evidences of plant phenological responses are known across the globe (Badeck et al., 2004; Cleland et al., 2007; Elzinga et al., 2007), from the Northern (Schwartz et al., 2006) to the Southern Hemisphere (Chambers et al., 2013), towards Europe (Fitter et al., 1995; Ahas and Aasa, 2006; Menzel et al., 2006), Russia (Ovaskainen et al., 2013) and China (Ge et al., 2015). Thus, one of the most appropriate indicator of climatic changes are phenophases of living beings. Phenology, the science of natural recurring events (Demarée and Rutishauser, 2011) analyses the timing of periodic life-history events (i.e. phenophases) such as budburst or first flowering of plants (Pau et al., 2011). Specifically, the first definition by Lieth (1974) says: 'Phenology is the study of timing of recurrent biological events, the causes of their timing with regard to biotic and abiotic forces, and the interrelation among phases of the same or different species'.

In moderate and cold climatic zones, phenological stages occurring in the spring season are particularly sensitive to their environment. Their adaptation to interannual day length can cause detectable changes in their growth activity if reinforced by increasing temperature (Rutishauser et al., 2007). Atmospheric teleconnection patterns, e.g. the North Atlantic Oscillation, influence both temperature and precipitation conditions of the Northern Hemisphere (Trigo et al., 2002; Hurrell et al., 2003; Bartholy et al., 2009; Mandl, 2009), and thus, indirectly the phenological patterns too (Menzel, 2003; Stenseth et al., 2003). Precipitation cannot be considered as a major driving factor at the mid-latitudes (Buermann et al., 2003), because it usually does not significantly explain variances of the spring plant development (Rutishauser et al., 2007). However, it is more important in arid and semi-arid regions (Lima and Rodal, 2010).

Eco-climatological studies referring for plant phenophases can often be used as bioindicators of climate change or proxies for temperature (Menzel, 2002, 2003; MillerRushing et al., 2008), especially when the seasonal timing of the phenological event is closely related to specific climatic conditions during plant development (Sparks et al., 2000; Aono and Kazui, 2008). The so-called climate proxies are preserved physical characteristics of the past that stand for direct measurements and can be utilized for climatological reconstructions (Rutishauser et al., 2007). Furthermore, vice versa, future climate projections can be used for the prediction of the proxy based on the strong relationship between the variables. Numerous studies reconstructed temperature conditions using different phenophases from available phenological data series (e.g., Holopainen et al., 2006; Lavoie and Lachance, 2006; Rutishauser et al., 2007; Aono and Kazui, 2008; Kiss et al., 2010). Although phenological data series compiled from historical records allow climatic reconstructions on shorter time-scale compared to other proxies, such as tree ring, pollen or ice core data, they are also important sources for analysing the past climate and prepare cross-validation independently (Dickinson and Bonney, 2012). Detailed analyses of heat sensitivity of different phenophases were carried out in Germany, Switzerland and UK (Rutishauser et al., 2009; Schleip et al., 2009), but not yet for the Carpathian Basin.

There are numerous endemic and climatic-endangered plant species living in the Pannonian biogeographical region. The enhanced protection of these species and their habitats under climatic changes is substantial, otherwise they might face to severe consequences and even extinction (Root et al., 2003; Estes et al., 2011). In order to understand and predict the impact of current climatic changes on plant phenophases, it is necessary to analyse phenological time series as a reference from the period when recent anthropogenic warming effect did not influence the local climate conditions. 
Unfortunately, most of the phyto-phenological data series recorded in the 19th century, suffer lacks both in time and space for the Carpathian Basin (Szalai et al., 2008). The available studies from this region (e.g. Walkovszky, 1998; Varga et al., 2009a,b, 2010; Szabó et al., 2016) rely on phenological data series recorded at the second half of 20th century, which period is already significantly influenced by the warming spring (Pongrácz et al., 2011; Cramer et al., 2014).

In the present study, we investigated the first flowering response of 16 wild plant species to interannual fluctuation of local seasonal temperatures (i.e., heat sensitivity of the flowering onset), also the rate of these species-specific sensitivities in order to test their applicability as proxy. The analyses were accomplished using first flowering data series, recorded in the second half of 19th century, in Hermannstadt and Mediasch located in Transylvania (nowadays in Romania). The following issues were addressed using different statistical methods: (i) characterization of the effect of mean temperatures in various time periods (monthly, bi-monthly, tri-monthly, etc) on flowering onset dates using a moving-window technique; (ii) determination of the effective temperature values $\left(\mathrm{T}_{\text {eff }}\right)$ estimated from the responses of each species; (iii) calculation of the temporal shifts of first flowering date as a response to $\mathrm{T}_{\text {eff }}$. Furthermore (iv) the plant species were ranked based on the temperature sensitivity of their first flowering dates; and (v) the accuracy of use of plant phenophases as proxy estimations was evaluated.

\section{Materials and methods}

\section{Phenological data}

The analyses are accomplished using flowering onset data sets of 16 wild plant species (Table 1) recorded in the second half of 19th century. The observations were carried out in the period 1851-1891, near Hermannstadt $\left(45^{\circ} 48^{\prime} \mathrm{N}, 2^{\circ} 9^{\prime} \mathrm{E}\right.$, named Sibiu today, located in Romania), by Ludwig Reissenberger, a local teacher deeply interested in natural science. The data recording is considered reliable and the documentation is precise due to the unchanged observer.

Table 1. Flowering onset data characteristics of the observed 16 plant species near Hermannstadt in the period 1851-1891. (SD= standard deviation; *herbaceous plants)

\begin{tabular}{l|l|l|l|c|c}
\hline \multirow{2}{*}{} & \multicolumn{2}{|c|}{ Species names } & \multicolumn{3}{c}{ Flowering onset (FO) } \\
\cline { 4 - 6 } & \multicolumn{2}{|c|}{} & $\begin{array}{c}\text { Mean FO } \\
\text { date }\end{array}$ & $\begin{array}{c}\text { Days after } \\
\text { 1 January }\end{array}$ & $\begin{array}{c}\text { 士 SD } \\
\text { [day] }\end{array}$ \\
\hline Sp-1 & Tussilago farfara L. & Coltsfoot* & 02 March & 62 & 15.7 \\
\hline Sp-2 & Scilla bifolia L. & Two-leaf squill* & 25 March & 85 & 10.0 \\
\hline Sp-3 & Taraxacum officinale W. & Common dandelion* & 05 April & 96 & 12.0 \\
\hline Sp-4 & Caltha palustris L. & Marsh marigold* & 07 April & 98 & 9.1 \\
\hline Sp-5 & Salix fragilis L. & Crack willow & 16 April & 106 & 9.9 \\
\hline Sp-6 & Ribes rubrum L. & Red currant* & 20 April & 110 & 9.0 \\
\hline Sp-7 & Fragaria vesca L. & Woodland strawberry* & 23 April & 113 & 8.9 \\
\hline Sp-8 & Orchis morio L. & Green-winged orchid* & 01 May & 122 & 8.2 \\
\hline Sp-9 & Syringa vulgaris L. & Common lilac & 02 May & 123 & 8.8 \\
\hline Sp-10 & Aesculus hippocastanum L. & Horse chestnut & 04 May & 125 & 8.5 \\
\hline
\end{tabular}




\begin{tabular}{l|l|l|c|c|c} 
Sp-11 & Euonymus europaeus L. & European spindle & 07 May & 128 & 8.1 \\
\hline Sp-12 & Salvia pratensis L. & Meadow sage* & 10 May & 130 & 8.7 \\
\hline Sp-13 & Dianthus carthusianorum L. & Carthusian pink* & 24 May & 144 & 9.3 \\
\hline Sp-14 & Robinia pseudoacacia L. & Black locust & 25 May & 145 & 9.1 \\
\hline Sp-15 & Sambucus nigra L. & Black elder & 26 May & 146 & 9.3 \\
\hline Sp-16 & Vitis vinifera L. & Common grape vine & 13 June & 165 & 7.3 \\
\hline
\end{tabular}

In order to test the accuracy of flowering dates as proxy, data have also been involved into analyses from Mediasch $\left(46^{\circ} 10^{\prime} \mathrm{N}, 24^{\circ} 21^{\prime} \mathrm{E}\right.$, named Mediaş today, located at cc. $50 \mathrm{~km}$ distance from Hermannstadt), for the period 1854-1865. (All the data mentioned above available in the Austro-Hungarian and Hungarian Meteorological Yearbooks.) At both sites, the date of flowering onset was defined as the date when some individuals from the whole plant population are totally flowering as it was given by the protocol of phenological observation in the 19th century (see in Meteorological Yearbooks). At Hermannstadt 24 plant species were observed by Reissenberger, however for detailed analyses 16 species were selected based on two criteria: (i) the plant was required to be common, widespread and possibly wild, in order to identify them by the observer easily, (ii) the average first flowering date was required to occur in the period from late-winter/early-spring until early-summer to enable comparisons of species-specific responses to different seasonal temperatures. According to similar investigations (Menzel, 2002, 2003; Fitter and Fitter, 2002), these early flowering species are more sensitive to climatic variations than the later (summer and/or autumn) flowering ones. In addition, half of the selected 16 species were herbaceous plants and the others were woody. Date of phenophase was given as the 'day of the year', i.e., the number of days elapsed since 1st January of a given calendar year.

\section{Climatological data}

The time series of monthly mean temperatures were also obtained from the mentioned Meteorological Yearbooks, and covered the same period (1851-1891 and 1854-1865) as the phenological observations originated from the two observational sites. The monthly means of air temperature were calculated from daily data. These daily time series were averaged and corrected from three daily measurements, recorded in the yearbooks. The meteorological measurements were carried out by standard devices of the Austrian weather service. Detailed descriptions of the measuring methods, conditions, devices, and applied corrections can be found in the yearbooks. After transforming the Réaumur degrees into standard Celsius degrees, and completing quality control, the monthly averaged data sets were considered as local homogeneous time series. The teleconnection pattern of North Atlantic Oscillation (NAO) has also been involved into our analysis as winter NAO index (Jones et al., 1997; Climatic Research Unit database), since several studies (e.g., Menzel, 2003; Gordo and Sanz, 2010; Szabó et al., 2016) confirmed the indirect effect of winter NAO on the timing of plant phenophases. 


\section{Statistical methods}

Both phenological and temperature data sets can be characterized by normal distribution, which was checked with Kolmogorov-Smirnov statistical test using 95\% confidence interval.

Linear regression analyses were applied to describe the possible long-term trends in the time series and possible relations between temperature and phenological data. The goal was to identify linear trend via regression of the observed time series against time and test the estimated slope coefficient of the linear regression equation for significance (Haan, 2002). The well-known least squares method was used for parameter estimation.

Cross correlation function $(\mathrm{CCF})$ was calculated between the two time series $\left(y_{t}\right.$ : phenological and $x_{t}$ : climatic) for identifying lags of the $x$-variable that might be useful predictors of $y_{t}$. CCF was defined as the set of sample correlations between $x_{t+l}$ and $y_{t}$ for $l=0$. Cross correlation values reflect the degree of linear relationship between the two data sets. Significant negative values for $r_{0}$ show if there was a negative correlation between the $x$-variable and the $y$-variable at time $t$ with 0 -lag (confirmed by t-test with 0.95 level of significance).

In phenological analyses, climatic variables are usually aggregated into averages over a month or more. Despite the loss of information due to aggregation, this aggregating method was applied in order to avoid both numerical problems and difficulties with interpretation arising from the high dimensional and correlated nature of daily weather data (Roberts, 2010). In this study bi-, tri-, and tetra-monthly mean temperatures were calculated from the monthly mean data to examine the relationships between the timing of first flowering and temperature data.

The effective temperature $\left(\mathrm{T}_{\mathrm{eff}}\right)$ is a nominal temperature that represents the heat conditions of the period, which is considered to possess the highest impact on the timing of flowering onset of a plant species. So, the $T_{\text {eff }}$ values represent different heat conditions due to different length of aggregating periods. The effective temperature periods were found by a 'moving window' technique: bi-, tri-, and tetra-monthly temperatures were calculated from the monthly means by shifting 1-month-steps. As a result of this method, newly aggregated time series were obtained such as $\mathrm{T}_{\mathrm{FM}}, \mathrm{T}_{\mathrm{MA}}$, $\mathrm{T}_{\mathrm{AM}}, \mathrm{T}_{\mathrm{MJ}} ; \mathrm{T}_{\mathrm{JFM}}, \mathrm{T}_{\mathrm{FMA}}, \mathrm{T}_{\mathrm{MAM}}, \mathrm{T}_{\mathrm{AMJ}}$; and $\mathrm{T}_{\mathrm{JFMA}}, \mathrm{T}_{\mathrm{FMAM}}, \mathrm{T}_{\mathrm{MAMJ}}$. The heat conditions of the winter-spring period prior to the time of flowering (even the previous summer and autumn conditions) can significantly influence as well as determine the date of flowering onset (Miller-Rushing and Primack, 2008). Hence the average temperatures of these periods can be considered as rough representation of the cumulative amount of heat. We determined the most effective temperature period for the phenophase of each species, by calculating serial CCF values. $\mathrm{T}_{\text {eff }}$ was selected by the highest absolute value of the CCF at $r_{0}$.

The temporal shifts of first flowering as a response to $\mathrm{T}_{\mathrm{eff}}$ and the heat sensitivity were described after applying linear regression. These characteristics were determined from the slope of the regression equations between the flowering and temperature time series. The regression coefficients indicate the effect (shift of flowering onset in days) of $1^{\circ} \mathrm{C}$ change in temperature in the certain period. Negative value of the regression coefficient indicates the advancement of flowering in response to increasing temperature.

To describe the species-specific relative response of flowerings to relative changes in $\mathrm{T}_{\text {eff }}$, both data series were converted into relative measures (expressed in percentages). These were obtained as follows: (i) determination of the anomalies of 
time series compared to the average of time series, (ii) sum of these anomalies without signs (this sum means the 100\%), and finally (iii) expression the anomalies with signs as a percent of the previously calculated amount of $100 \%$. The obtained relative responses of flowerings were considered as rough indicators of heat sensitivity characterising the plant species. By this indicator the plants were ranked and compared in terms of possible utilization as proxy.

In order to test the flowering onset of the selected plants as proxy data for local average seasonal temperatures (assuming relatively constant heat sensitivity in at least $50 \mathrm{~km}$ vicinity of the Hermannstadt site), phenological and temperature data of Mediasch (period: 1854-1865) were involved into the analysis. In case of 14 plant species observed at both places, by replacing the phenological data of Mediasch into the regression equation established on the relation between the phenological and temperature data of Hermannstadt, a robust estimation of local effective temperature was gained. The statistical analysis was carried out with codes written in FORTRAN language and with the Statistica software package (version 6.1, StatSoft Inc., USA).

\section{Results}

\section{Characteristics of studied time series}

\section{Observed temperature data}

According to the completed trend analysis, significant temporal trend was not detected in any of the temperature time series of Hermannstadt (1851-1891) and Mediasch (1854-1865), except mean temperature of April at Hermannstadt $(p<0.05)$, which was detrended for further analyses. After comparing monthly temperature data of the two locations, Mediasch was warmer than Hermannstadt by $1.04{ }^{\circ} \mathrm{C}$ on a yearly basis. Such difference could be resulted from the microclimates caused by differences in topographical conditions. Nevertheless, the general temperature conditions are quite similar at both places. As preliminary analysis showed, the early spring temperature series were significantly synchronously fluctuating at the two sites in the same period.

\section{Overview of flowering onset data}

Plants were selected from species observed at Hermannstadt flowering from late winter to early summer. The means of flowering onset dates with their standard deviations are listed for each species in Table 1. In the first part of the flowering onset temporal rank the herbaceous plants, in the second part the woody plants appear typically, which is reasonable when considering plant physiology.

Standard deviation (SD) of the first flowering time was decreasing from the earlier to later flowering plants due to the higher variability of mean temperatures in cooler months (January - March) (Fig. 1). The earliest spring flowering plant was Tussilago farfara, which was characterized by relatively high SD (15.7 days) and total range (75 days). In contrast, the early summer flowering Vitis vinifera had the lowest SD among the examined species and significantly lower range (47 days) than the others. The group of early May flowering plants (i.e., Orchis morio, Syringa vulgaris, Aesculus hippocastanum and Euonymus europaeus) as well, as the group of late May flowering species (i.e., Dianthus carthusianorum, Robinia pseudoacacia and Sambucus nigra) were characterized by similarly high minimum, maximum and SD values within the groups (Table 1). 


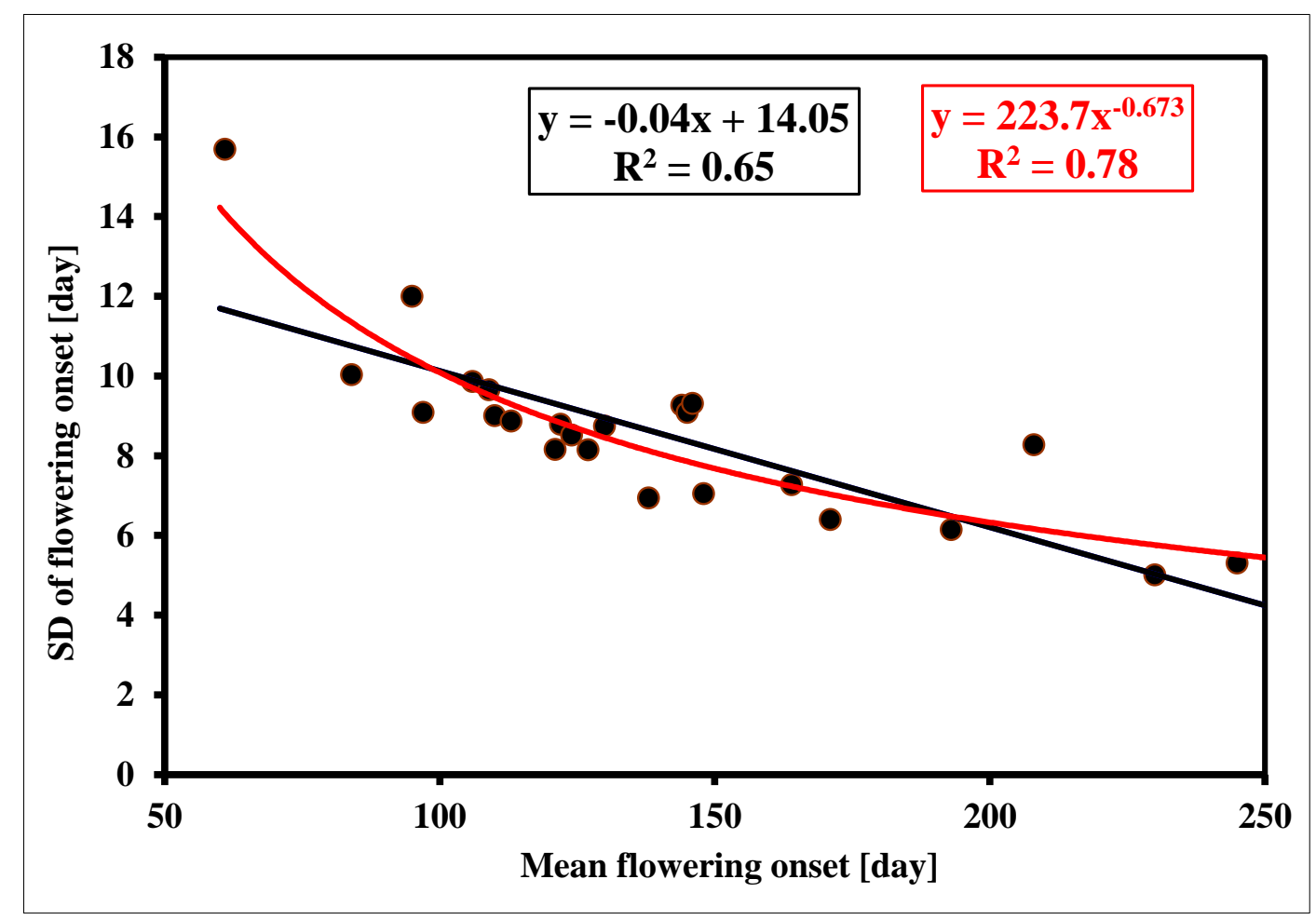

Figure 1. Relationship between mean flowering onsets and their standard deviations (SD) in case of plants observed (1851-1891) near Hermannstadt. Both linear and exponential regressions clearly show significant decrease of SD towards the late flowering plant species.

Significant temporal trend was not detected in any of the time series. Based on the CCF values, flowering time series significantly synchronously fluctuated not just intralocally (between species), but interlocally (between locations) as well. In order to illustrate this synchrony, the temporal patterns of FO of four plants are drawn in Fig. 2. The sharp yearly fluctuation of Tussilago farfara ( $\mathrm{Sp}-1)$ - as the earliest flowering plant - is conspicuous, indicating a strong sensitivity to late-winter temperatures.

\section{Impact of temperature on flowering onset}

In order to determine the strength of the relationship between the timing of flowering onset and temperature data, correlation coefficients $\left(r_{0}\right)$ at 0 lag CCFs were calculated (Table A; Appendix). The signs of $r_{0}$ were mostly negative in case of winter-spring months, indicating that plants responded to higher temperatures with earlier flowering onsets (Fig. 3). 


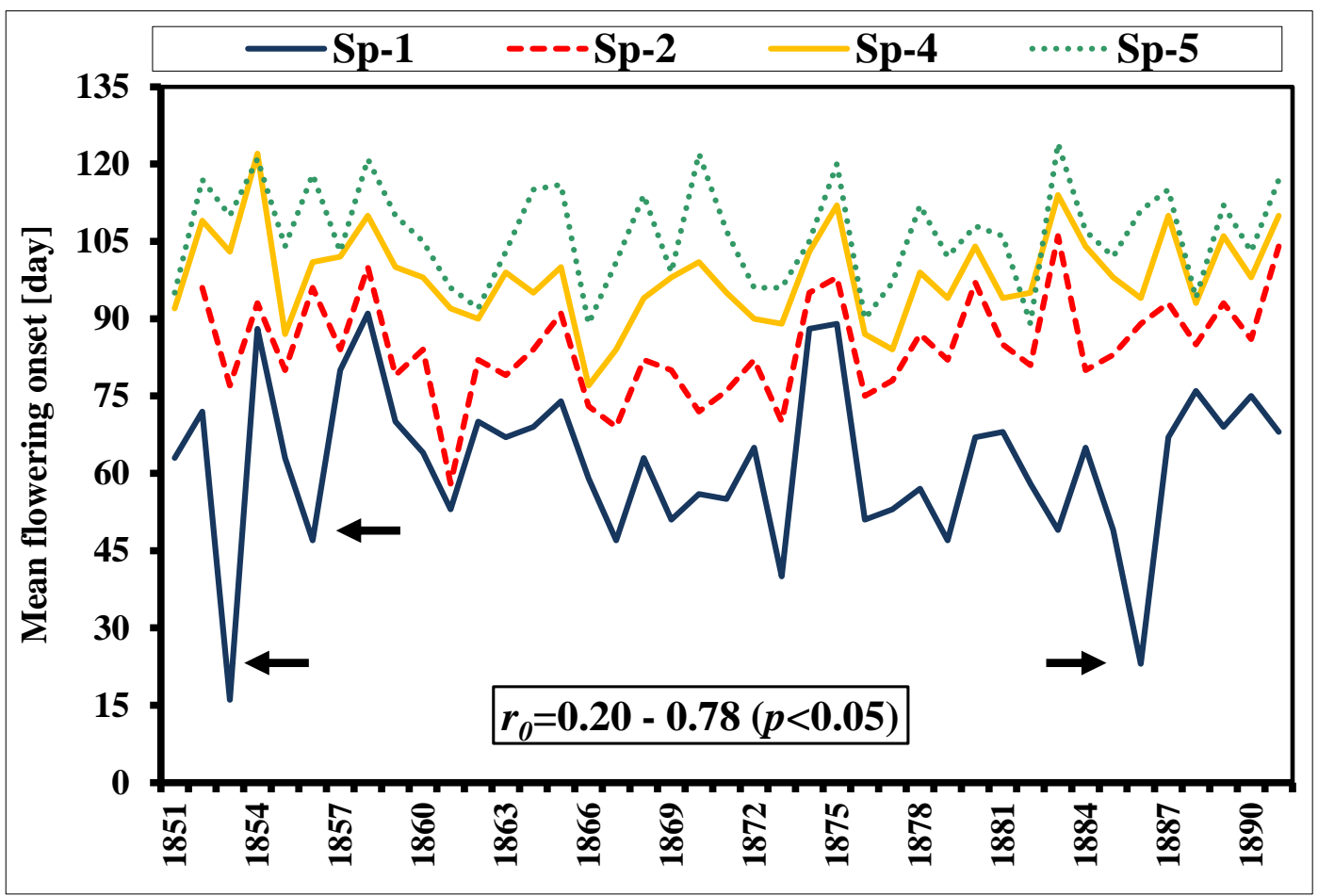

Figure 2. The synchronous fluctuations of four early flowering plants near Hermannstadt (1851-1891). The value of correlation coefficient $\left(r_{0}\right)$ was higher between the later ones, Scilla bifolia (Sp-2), Caltha palustris (Sp-4) and Salix fragilis (Sp-5), than the earliest flowering Tussilago farfara (Sp-1). The black arrows point at the marked deviations of $T$. farfara due to late winter heat waves.

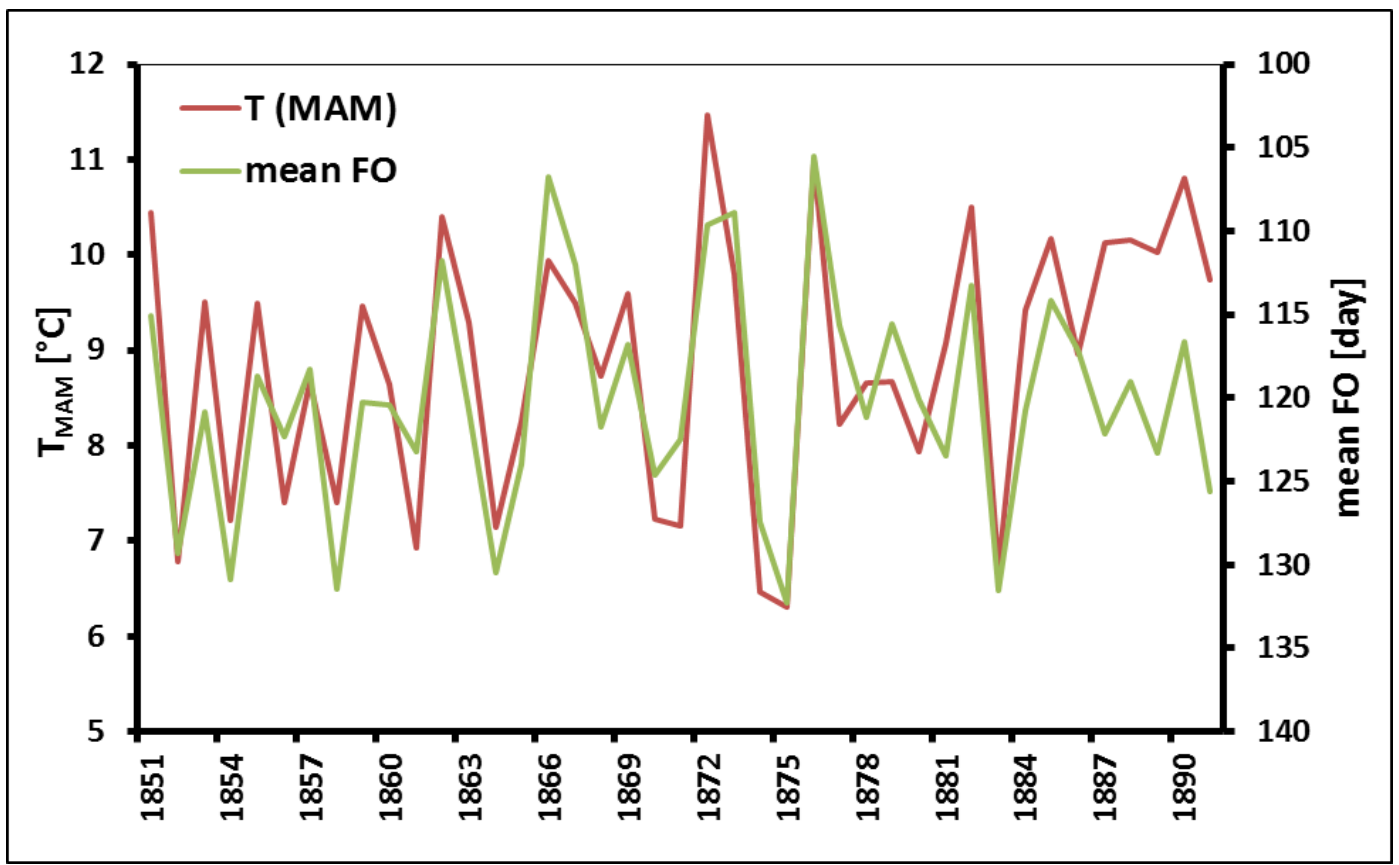

Figure 3. Mean flowering onset (FO) of 16 plant species and tri-monthly mean temperature of the period March-May recorded near Hermannstadt (1851-1891). The high negative value of the correlation coefficient indicates strong reverse relation between the timing of the phenophase and heat conditions of spring. 
In late winter - spring seasons, strong correlations $(\mathrm{p}<0.05)$ were found between the flowering onset data series and monthly, multi-monthly mean temperature time series in case of most species (indicated in bold in Table A; Appendix). Effective temperatures of 16 plant species were determined by serial correlations using 'moving window' method described above (Materials and methods). The effect of mean monthly, bi-monthly, trimonthly, tetra-monthly temperatures on the first flowerings was determined in the first step. Then, from the obtained different strength of FO responses, each species-specific effective temperature value $\left(\mathrm{T}_{\text {eff }}\right)$ was estimated. The most effective temperature period for a certain plant was selected by the highest absolute value of $r_{0}$ (Fig. 4).

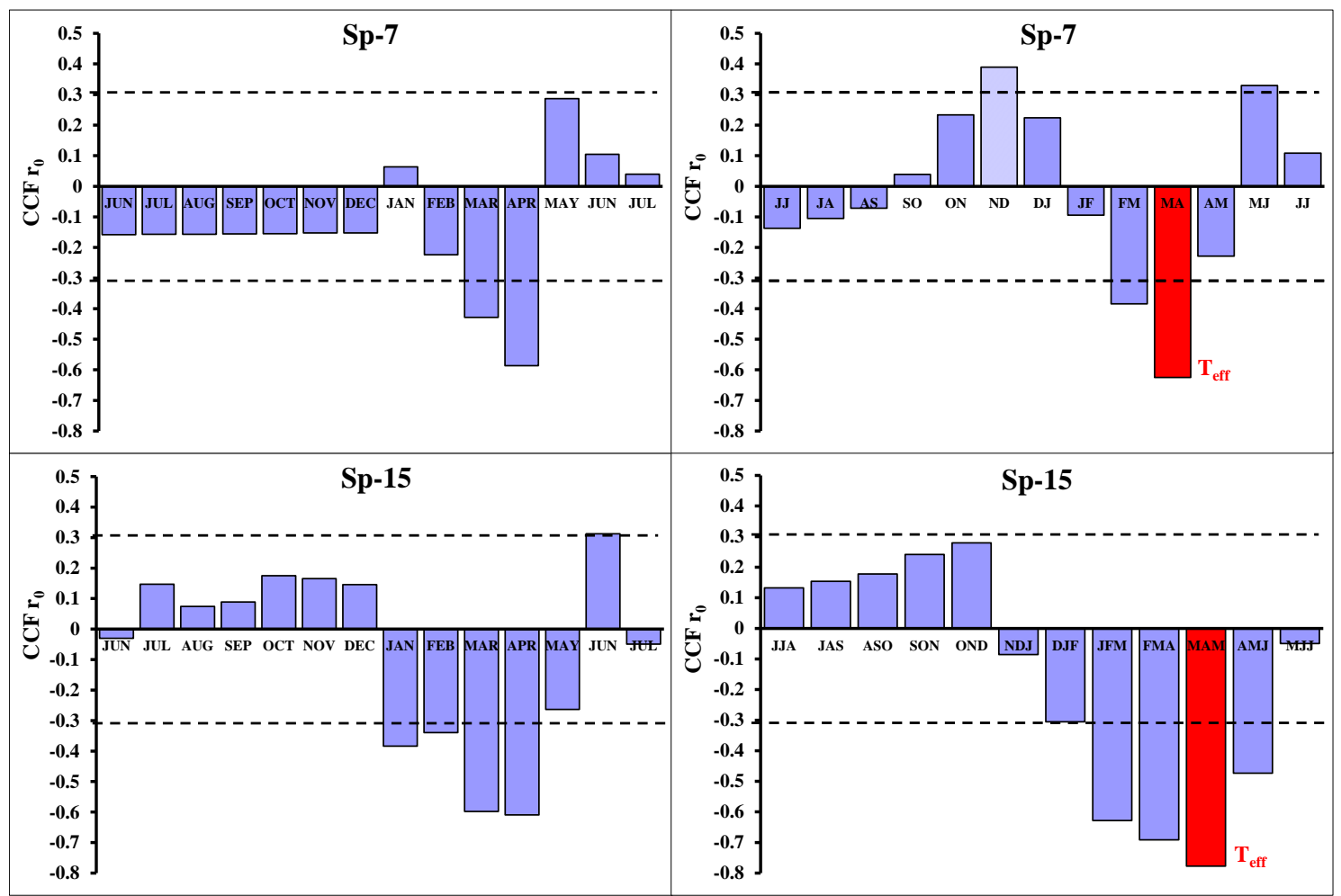

Figure 4. Two examples (Sp-7: Fragaria vesca and Sp-15: Sambucus nigra) for finding the most effective temperature (Teff) of flowering onsets using serial cross correlation functions (CCF) and moving window technique with different number (1,2, 3 and 4) of months. Scattered lines on the graphs indicate the threshold of significant $(p<0.05)$ correlation coefficient values $(r 0)$.

Periods of the effective temperature $\left(\mathrm{T}_{\text {eff }}\right)$ and periods with high FO-T correlation $\left(r_{0}>0.5\right)$ are given in Table 2. for the 16 examined plant species. The majority of plants expressed the highest correlation with the bi-monthly mean temperature preceding the flowering onset, however there were some examples, which produced the highest $r_{0}$ with tri-monthly period (e.g. Tussilago farfara - JFM) or even longer, tetra-monthly period (e.g. Vitis vinifera - MAMJ). In case of almost all plants the DJFM and the JFMA periods were the first 'negative-effect' (i.e. causing advanced FO) periods, while for Tussilago farfara and Taraxacum officinale the mean temperature of the late autumn - winter (ONDJ, NDJF) period found to be also significantly effective on the timing of subsequent flowering onset (Table A; Appendix). 
Table 2. The effective temperature $\left(T_{\text {eff }}\right)$ periods and the 1-month periods of temperature with the highest influence $(r>0.5 ; p<0.05)$ on the timing of flowering onset $(F O)$ of the 16 studied plant species observed near Hermannstadt (1851-1891).

\begin{tabular}{c|c|c}
\hline & $\begin{array}{c}\text { Period of } \\
\mathbf{T}_{\text {eff }} \text { (multi- } \\
\text { months) }\end{array}$ & $\begin{array}{c}\text { Correlation FO-T } \\
(\boldsymbol{r} \boldsymbol{>} \mathbf{0 . 5})\end{array}$ \\
\hline Sp-1 & JFM & Feb \\
\hline Sp-2 & FM & Feb, Mar \\
\hline Sp-3 & FM & Mar \\
\hline Sp-4 & FMA & Mar \\
\hline Sp-5 & MA & Mar, Apr \\
\hline Sp-6 & MA & Mar, Apr \\
\hline Sp-7 & MA & Apr \\
\hline Sp-8 & MA & Mar, Apr \\
\hline Sp-9 & MA & Apr \\
\hline Sp-10 & MA & Apr \\
\hline Sp-11 & MA & Mar, Apr \\
\hline Sp-12 & A, MA & Apr \\
\hline Sp-13 & MAM & Apr \\
\hline Sp-14 & AM & Apr, May \\
\hline Sp-15 & MAM & Mar, Apr \\
\hline Sp-16 & MAMJ & Apr, May \\
\hline
\end{tabular}

For half of the species a 'positive effect' (i.e. causing delayed FO) by the multimonthly mean temperatures of previous years in summer-autumn season was observed. In case of eight plants, significant $(\mathrm{p}<0.05)$ positive values of $r_{0}$ were found, associated with relation to bi-, tri-, tetra-monthly summer - autumn mean temperatures and the mean flowering onset. The FO of Scilla bifolia was influenced by the mean temperature of late summer - early autumn period; similarly the FO of Salix fragilis, Syringa vulgaris, Dianthus carthusianorum and Robinia pseudoacacia by the mean temperature of autumn period; and FO of Fragaria vesca by the mean temperature of late autumn winter period were affected as well. Finally, for Aesculus hippocastanum the FO seemed to be influenced by the temperature conditions of the entire June to December period.

\section{Species-specific heat sensitivity of flowering onset}

Flowering sensitivities of the selected plants in response to their effective temperatures were different. Based on results of the regression analysis (RA) the 16 plants species were ranked. The rank was created by (i) the correlation coefficients between the first flowering dates and the $\mathrm{T}_{\text {eff }}$ temperatures (Fig. 5 and Fig. 6), (ii) the temporal shifts (expressed in day $/{ }^{\circ} \mathrm{C}$ ) of first flowering as a response to a unit change in $\mathrm{T}_{\text {eff }}$ (Fig. 5), (iii) the relative response of first flowering to a relative change in $\mathrm{T}_{\text {eff. }}$ The negative value of slope $(a)$ referred to the straightforward feature that higher mean 
temperature of previous periods of phenophase caused advanced flowering onset. These responses of the flowering onsets were species-specific and significantly $(\mathrm{p}<0.05)$ measurable (Figures 5-6).
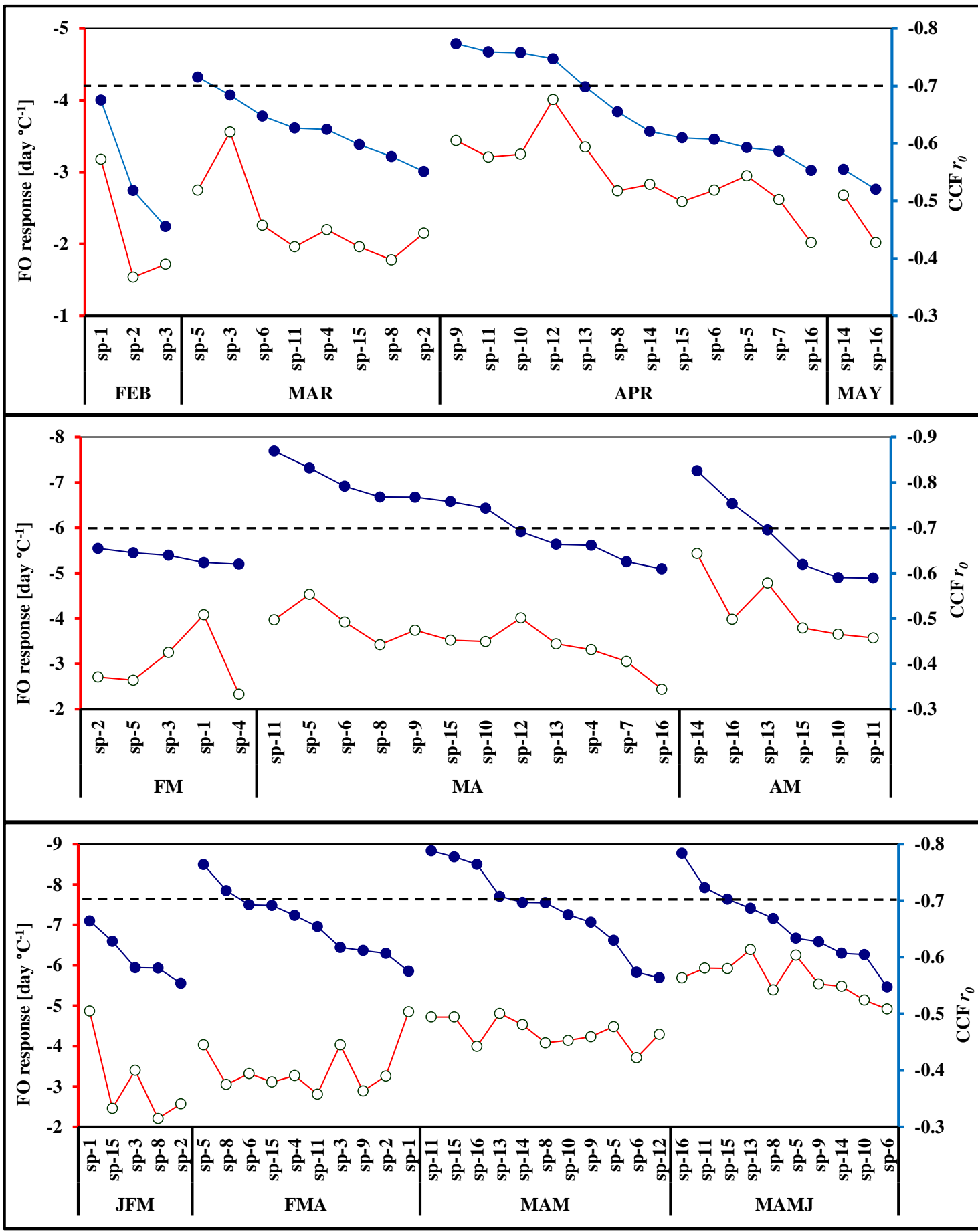

Figure 5. Rank of 16 plant species by significant $(p<0.05)$ correlations (vertical axis on the right, filled markers) and response of flowering onsets (expressed in the value of slopes originated from regression equations; vertical axis on the left, empty markers) given to the mean temperatures of various time periods based on observations near Hermannstadt from 1851-1891. The straight dashed lines indicate the threshold of the strongest relations between the phenophase and the mean temperature. 


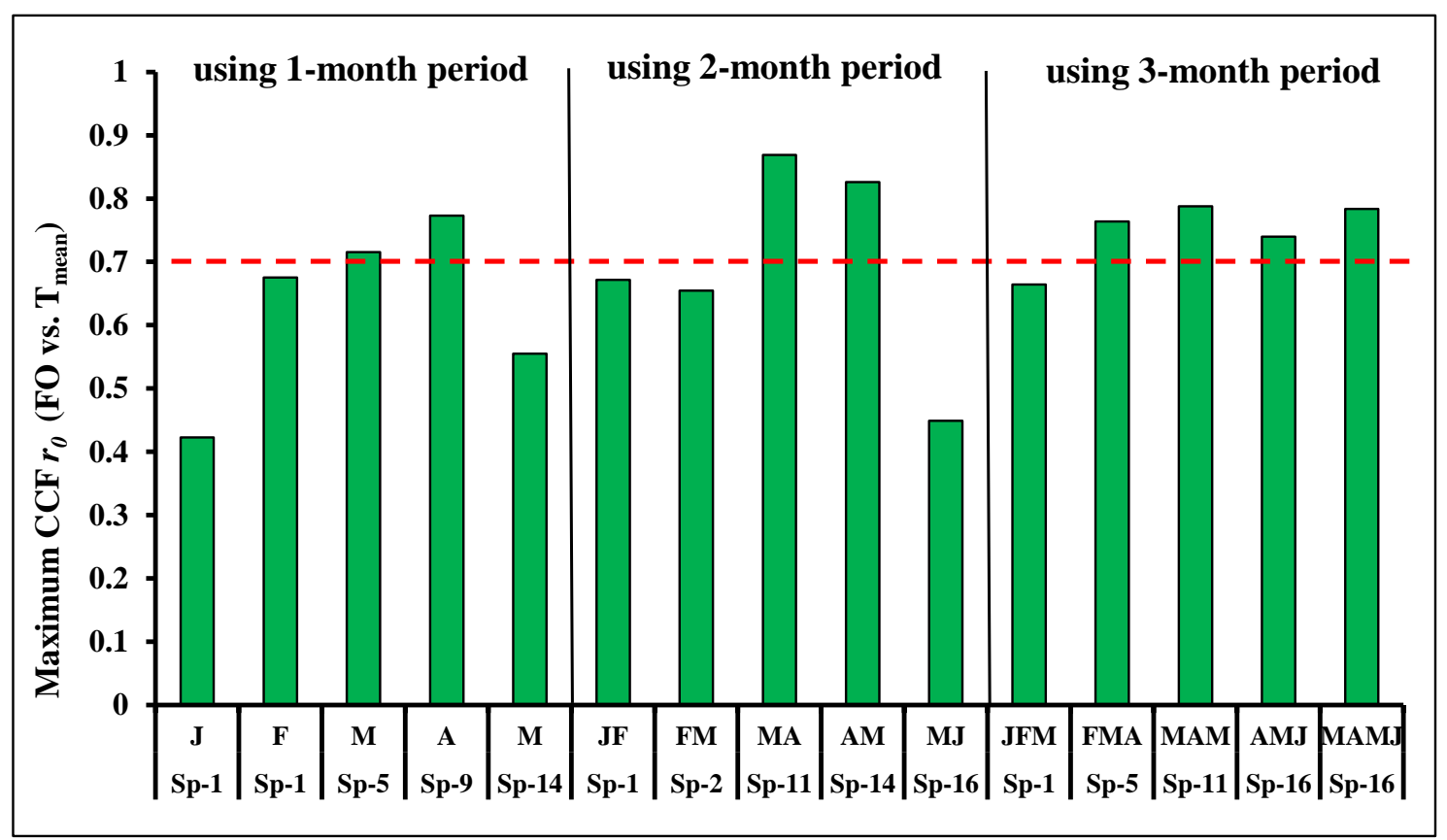

Figure 6. The highest significant $C C F \mathrm{rO}(\mathrm{p}<0.05)$ values found by the moving window method between flowering onset $(F O)$ and mean temperature $\left(T_{\text {mean }}\right)$ for periods of different length based on observations near Hermannstadt, 1851-1891. The red straight dashed line indicates the threshold of the strongest relationships between the phenophase and the mean temperature.

Plants related to the same $\mathrm{T}_{\text {eff }}$ period were compared and ranked by the strength of the relation $\left(r_{0}\right)$ between $\mathrm{FO}$ and $\mathrm{T}_{\text {eff. }}$ Then the magnitude of the response to a unit change in $\mathrm{T}_{\text {eff }}(a)$ was considered. In Fig. 5 the strongest relationships $\left(r_{0}>0.5\right)$ of plants belong to different monthly and multi-monthly effective temperature periods are shown.

The strongest correlation and the highest response to $1^{\circ} \mathrm{C}$ change in temperature were found in the following cases. Correlation coefficients $\left(r_{0}\right)$ and slopes (a) in cases of the mean temperature of February $\left(\mathrm{T}_{\mathrm{FEB}}\right)$, March $\left(\mathrm{T}_{\mathrm{MAR}}\right)$, April $\left(\mathrm{T}_{\mathrm{APR}}\right)$ and May $\left(\mathrm{T}_{\mathrm{MAY}}\right)$ were considered. For $\mathrm{T}_{\mathrm{FEB}}$ the highest reaction was shown by Tussilago farfara $\left(r_{0}=-0.68 ; a=-3.18\right)$; for $\mathrm{T}_{\mathrm{MAR}}$ by Salix fragilis $\left(r_{0}=-0.72 ; a=-2.75\right)$ and Taraxacum officinale $\left(r_{0}=-0.68 ; a=-3.56\right)$; for $\mathrm{T}_{\mathrm{APR}}$ by Syringa vulgaris $\left(r_{0}=-0.77 ; a=-3.44\right)$ and Vitis vinifera $\left(r_{0}=-0.75 ; a=-4.01\right)$; and for $\mathrm{T}_{\mathrm{MAY}}$ by Robinia pseudoacacia $\left(r_{0}=-0.56\right.$; $a=-2.68)$ as it is drawn in Fig. 5.

In case of bi-monthly temperature means, for $\mathrm{T}_{\mathrm{FM}}$ the relationships of the five earliest flowering plants were nearly the same $\left(r_{0}=-0.62-0.65\right)$, but in terms of the FO response, Tussilago farfara seemed to be the most 'sensitive' ( $a=-4.08)$. $\mathrm{T}_{\mathrm{MA}}$ influenced 12 plants effectively, in which case Euonymus europaeus was at the first place of the ranked series. $\mathrm{T}_{\mathrm{AM}}$ showed the strongest correlation with the late spring flowering plants, the highest response to $1^{\circ} \mathrm{C}$ change in temperature was expressed by Robinia pseudoacacia $\left(r_{0}=-0.83 ; a=-5.43\right)$.

In terms of the tri- and tetramonthly effective temperature periods in the ranked plant series belonging to $\mathrm{T}_{\mathrm{JFM}}$, the first was again Tussilago farfara $\left(r_{0}=-0.66 ; a=-4.87\right)$ and a late spring plant, Sambucus nigra $\left(r_{0}=-0.63 ; a=-2.46\right)$ occurred in the ranked series, too. The strongest relationship was detected and the highest reaction of $\mathrm{FO}$ was given to $1^{\circ} \mathrm{C}$ change in $\mathrm{T}_{\mathrm{FMA}}$ by Salix fragilis $\left(r_{0}=-0.76 ; a=-4.03\right)$; and in $\mathrm{T}_{\mathrm{MAM}}$ by Euonymus 
europaeus ( $\left.r_{0}=-0.79 ; a=-4.72\right)$ and Sambucus nigra $\left(r_{0}=-0.78 ; a=-4.72\right)$. Finally, in case of the tetramonthly $\mathrm{T}_{\text {MAMJ }}$ Vitis vinifera $\left(r_{0}=-0.78 ; a=-5.69\right)$ showed the strongest relation between $\mathrm{T}_{\text {eff }}$ and $\mathrm{FO}$.

Taking into consideration the FOs climatological utilization (e.g. as a proxy), the highest $\mathrm{CCF} r_{0}$ values per period are shown for each monthly, multi-monthly 'time-window' in Fig. 6. Interestingly, to all investigated time periods a total of 7 plants expressed the strongest response as 'thermal indicators'. These species (Tussilago farfara, Scilla bifolia, Salix fragilis, Syringa vulgaris, Euonymus europaeus, Robinia pseudoacacia, Vitis vinifera) were mostly characterized by the highest FO responses as well.

In order to determine a rough but comparable indicator of heat sensitivity of FO, regression analyses were carried out on the time series of relative changes of FO and monthly, multi-monthly temperatures. Fig. 7 is an illustration for the regression slope assessment of sensitivity using relative monthly temperature and flowering changes. From a geometric aspect, heat sensitivity is the higher, the regression line fits the better to the $45^{\circ}$ line, namely to the theoretic, perfect phyto-thermometer. Thus, in the example of the figure, Euonymus europaeus (Sp-11) $\left(a=-0.90 ; R^{2}=0.69\right)$ responded more sensitively to $1^{\circ} \mathrm{C}$ change in mean temperature of MA period, than Fragaria vesca $(\mathrm{Sp}-7)\left(a=-0.60 ; R^{2}=0.39\right)$.
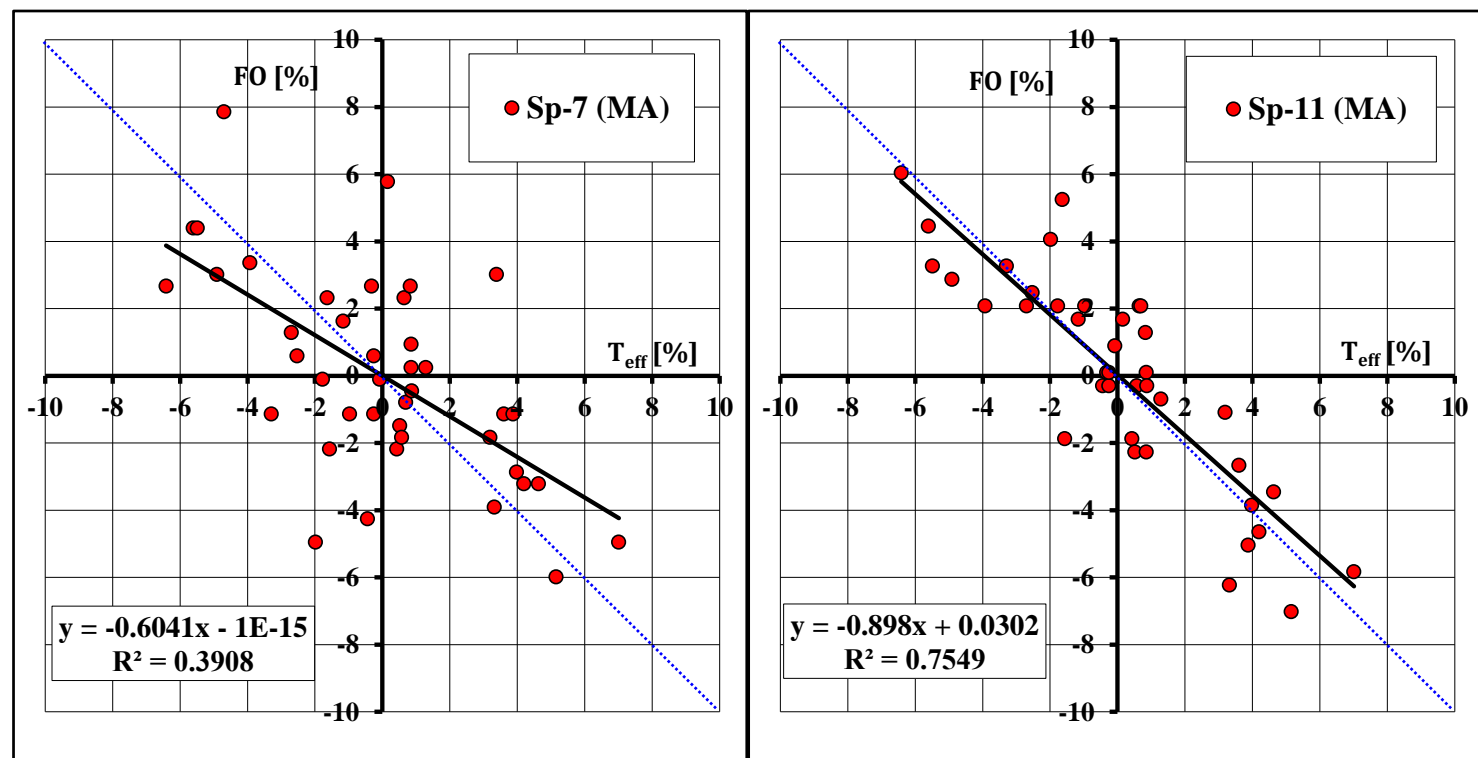

Figure 7. Example of regression slope assessment of heat sensitivity using relative bi-monthly effective temperature $\left(T_{\text {eff }}\right)$ as explanatory variable and relative changes of flowering onset $(F O)$

as dependent variable. In this way the plants are comparable as thermometers for the same period. (Sp-7: Fragaria vesca; Sp-11: Euonymus europaeus; $M A=T_{\text {eff }}$ period; solid line $=$ linear regression line; dotted line $=$ line with $a=-1$ as a $45^{\circ}$ slope) 


\section{Testing flowering onset as a proxy}

The phenophase onset was tested as temperature proxy using datasets from Mediasch (Fig. 8). Results of the regression analyses on temperature and phenological data of Hermannstadt were applied to estimate the effective temperature of 14 plant species observed at both places. According to the proxy-testing, the later the plant begins to flower, and the longer the period of effective temperature is (i.e. multi-monthly mean temperature was the most effective), the more accurate the estimation of $\mathrm{T}_{\mathrm{eff}}$ by the FO.

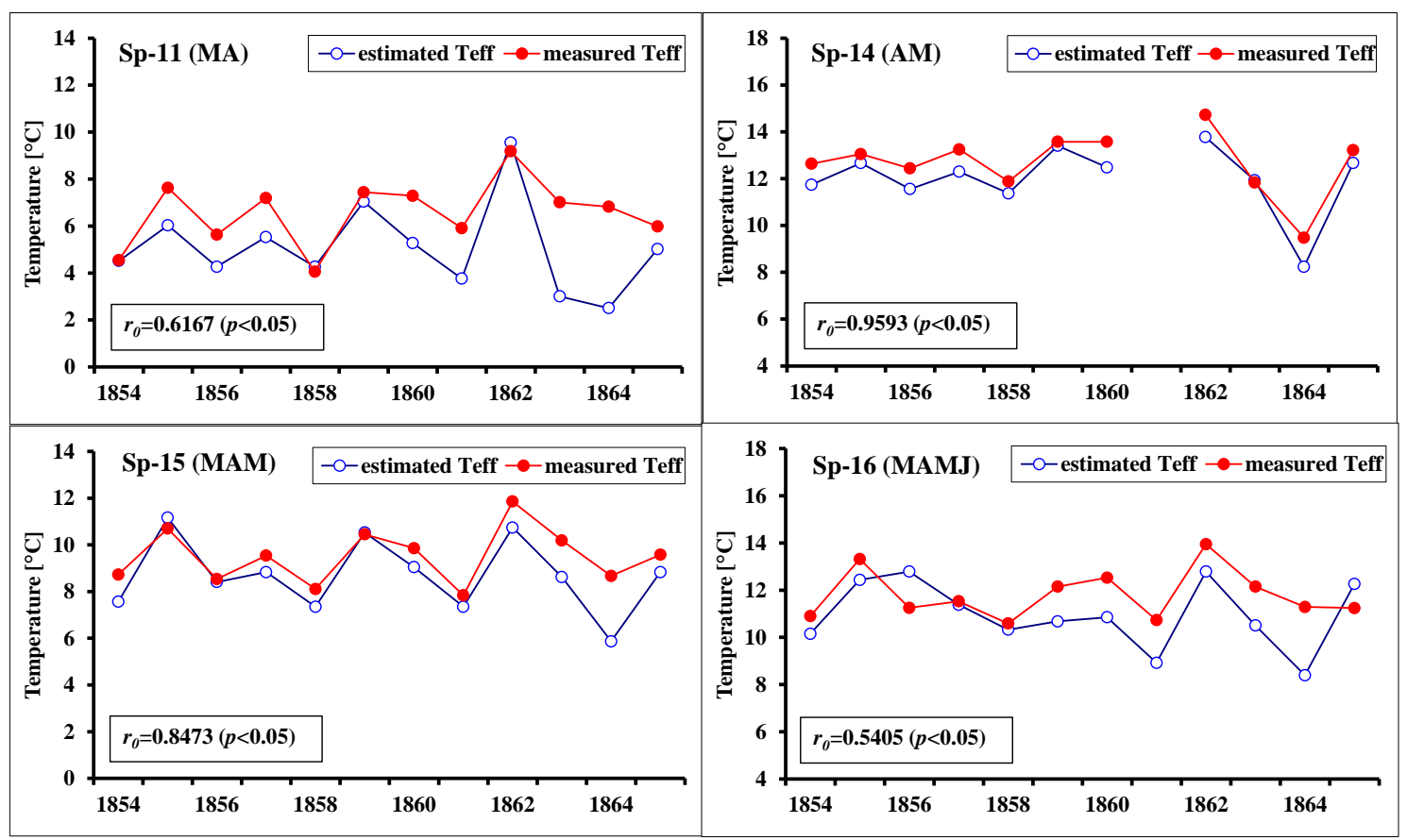

Figure 8. Four examples of testing the accuracy of the proxy by estimating the effective temperature $\left(T_{\text {eff }}\right)$ from the flowering onset data of Mediasch based on the linear regression equations on temperature and phenological data of Hermannstadt in case of 14 plant species observed (18541865) at both places. (Sp-11: Euonymus europaeus; Sp-14: Robinia pseudoacacia; Sp-15: Sambucus nigra; $S p$-16: Vitis vinifera; $T_{\text {eff }}$ periods: $\left.M A, A M, M A M, M A M J\right)$

In Fig. 8 the four most accurate indicator plants are shown, which were selected by considering the previous results of heat sensitivity rankings. These were mostly late spring - early summer flowering species, namely Euonymus europaeus (Sp-11), Robinia pseudoacacia (Sp-14), Sambucus nigra (Sp-15), and Vitis vinifera (Sp-16). In case of Robinia pseudoacacia the average difference between measured and estimated $\mathrm{T}_{\text {eff }}\left(=\mathrm{T}_{\mathrm{AM}}\right)$ was $0.50{ }^{\circ} \mathrm{C}$, and $\mathrm{SD}$ was $0.41{ }^{\circ} \mathrm{C}$. For Sambucus nigra concerning $\mathrm{T}_{\mathrm{MAM}}$ the same values were $0.34{ }^{\circ} \mathrm{C}$ and $0.84{ }^{\circ} \mathrm{C}$, respectively. Finally, in terms of Vitis vinifera these values appertain to $\mathrm{T}_{\text {MAMJ }}$ were found as $0.32{ }^{\circ} \mathrm{C}$ and $1.24{ }^{\circ} \mathrm{C}$, respectively. In summary, FO data of the most sensitive heat indicator plants were applicable to estimate the $\mathrm{T}_{\text {eff }}$ data - as a first guess. The accuracy of estimation was between $1.0^{\circ} \mathrm{C}$ and $1.5^{\circ} \mathrm{C}$. 


\section{Discussion}

In the first part of this study the main characteristics of the flowering phenological and climatological time series, as well as their relationships were analysed. Since several previous studies (e.g., Hurrell et al., 2003; Menzel, 2003) confirmed that the winter/early spring temperature variability in the 20th century is significantly influenced by the teleconnection pattern of North Atlantic Oscillation (NAO), we also involved the winter NAO index into our phenological analyses. Our results are consistent with other studies (Auer et al., 2001; Böhm et al., 2001) found for climatological conditions in the second part of the 19th century, namely, the temperature time series did not contain any increasing or decreasing trend in this part of Europe. Furthermore, other studies focusing especially on NAO (Jones et al., 1997; Hurrell et al., 2003; Osborn, 2006) did not find any significant trend in winter NAO time series, either. Our climatological results strengthen these findings and call for attention to discover more historical time series, the importance of reconstructions and the need for further research.

Considering the quantification of the FO - T - NAO impact-system, we have also found that the flowering onset (FO) is primarily influenced by the heat conditions of the preceding period of flowering (Menzel, 2003; Miller-Rushing and Primack, 2008; Szabó et al., 2016), and the impact of winter NAO was negligible. Based on our findings the majority of plants are affected most strongly by the mean bi-monthly or trimonthly temperatures prior to the date of flowering. In addition, several plants (such as the flowering onset of Scilla bifolia) were also influenced by the heat conditions in late summer - autumn of the previous year, as similar conclusion was drawn by Gordo and Sanz (2010) for the Mediterranean region.

The main aim of this paper was to analyse the species-specific heat-sensitivity of flowering onset characteristics of different plant species. Only a few studies (e.g. Root et al., 2005; Aono and Kazui, 2008; Rutishauser et al., 2009) focused on this topic using this perspective so far. According to studies of 20th century data major synchronous break was found in phenological time series during the 1980s in Europe (Dose and Menzel, 2004; Schleip et al., 2006). Furthermore significant earlier shift in flowering onset dates (1952-2000) of common dandelion, black elder, as well as in case of the black locust (1951-1994) were shown by Szabó et al. (2016) and Walkovszky (1998) among our examined species. In contrary their findings in the neighbourhood country, Hungary, we did not find linear trend in the flowering onset data - probably because our data were recorded during the 19th century when the impacts of human induced climatic changes were not yet as influential as in the late $20^{\text {th }}$ century.

Our central addressed issue of testing flowering onset as proxy variable for temperature was based on our heat sensitivity results. According to the validation tests on data from Mediasch, the flowering onsets of Robinia pseudoacacia and Vitis vinifera proved to be the most accurate phyto-thermometers. Hence, these two plants can be utilized to provide data with highest confidence as proxy for estimating the mean temperature of their effective temperature periods (Robinia pseudoacacia - April-May; Vitis vinifera - March-April-May-June) in the examined time period and region. Overall, the 14 tested plant species estimated their effective temperature with $1-1.5{ }^{\circ} \mathrm{C}$ accuracy. Taking into account the general climatological differences of the two sites (Mediasch is warmer in yearly average by $1.04{ }^{\circ} \mathrm{C}$ compared to Hermannstadt), the average bias of proxy estimations could be slightly reduced by applying a simple additive correction. Therefore, this method in first approach is appropriate as a robust estimation of mean temperature from flowering data. The estimation is robust which 
originate from the uncertainty of geographical factors, which can explain the spatial variance of flowering dates (Wang et al., 2015). Furthermore, this uncertainty also comes from the rough resolution of the temperature records, since the monthly and multi-monthly averages of temperature time-series are good representatives of the spring heat conditions, but not as accurate as if the effective temperatures were obtained based on daily data (e.g. degree-day calculation; see Schwartz, 2013). If more detailed data series (either temporally or spatially) are available, the method can be refined and resulted in a more accurate estimation, which is of interest in order to better understand past climates of periods or locations where no instrumental records are available.

\section{Conclusions}

- Decomposing the total climatic impacts, the temperature proved to be the main determining variable for the timing of flowering onset, whereas the impact ofthe winter NAO was negligible in the second part of the 19th century in Transylvania. The time series of flowering onset and effective temperature fluctuated significantly synchronously, nevertheless, temporal trends were not detected in the datasets (1851-1891).

- The species-specific effective temperature values obtained from the flowering onset response to monthly, bi-monthly, tri-monthly average temperatures were calculated and applied for ranking the plant species. The species-specific heat sensitivities were determined via examining the temporal shifts of first flowering date as a response to effective temperatures. According to the species-specific heat sensitivities the most accurate phyto-thermometers (Robinia pseudoacacia and Vitis vinifera) were selected.

- The beginning of flowering phenophase was tested as proxy for the effective temperature, and the accuracy of different plant proxies ranged between $1.0{ }^{\circ} \mathrm{C}$ and $1.5^{\circ} \mathrm{C}$. Thus our method is appropriate for climatological utilization as a robust estimation of heat conditions, when no other records are available.

Acknowledgements. The authors wish to acknowledge the help of Ferenc Kádár and István Matyasovszky in data analysis and commenting on an early draft of the study. Research leading to this paper has been partially supported by the Hungarian National Science Research Foundation under grant K-78125, the European Union and the European Social Fund (TAMOP-4.2.1/B-09/1/KMR-2010-0003). The principle author finalised the paper with the support of the Martí-Franquès Research Grant Program (reference number: 2014PMF-PIPF-21).

\section{REFERENCES}

[1] Ahas, R., Aasa, A. (2006): The effects of climate change on the phenology of selected Estonian plant, bird and fish populations. - International Journal of Biometeorology 51: 17-26.

[2] Auer, I., Böhm, R., Schöner, W. (2001): Austrian long-term climate 1767-2000 Multiple instrumental climate time series from Central Europe. Zentralanstalt für Meteorologie und Geodynamik, Wien, 147 pp. 
[3] Aono, Y., Kazui, K. (2008): Phenological data series of cherry tree flowering in Kyoto, Japan, and its application to reconstruction of springtime temperatures since the 9th century. - International Journal of Climatology 28:905-914.

[4] Badeck, F.W., Bondeau, A., Böttcher, K., Doktor, D., Lucht, W., Schaber, J., Sitch, S. (2004): Responses of spring phenology to climate change (Research review). - New Phytologist 162:295-309.

[5] Bartholy, J., Pongrácz, R., Gelybó, Gy. (2009): Climate signals of the North Atlantic Oscillation detected in the Carpathian basin. - Applied Ecology and Environmental Research 7:229-240.

[6] Bartholy, J., Pongrácz, R., Nagy, J., Pieczka, I., Hufnágel, L. (2012): Regional climate change impacts on wild animal's living territory in Central Europe. - Applied Ecology and Environmental Research 10:107-120.

[7] Böhm, R., Auer, I., Brunetti, M., Maugeri, M., Nanni, T., Schöner, W. (2001): Regional temperature variability in the European Alps: 1760-1998 from homogenized instrumental time series. - International Journal of Climatology 21:1779-1801.

[8] Buermann, W., Anderson B., Dickinson R.E., Lucht W., Potter C.S., Myneni R.B. (2003): Interannual covariability in Northern Hemisphere air temperatures and greenness associated with El Niño-Southern Oscillation and the Arctic Oscillation. - J. Geophys. Res. 108:4396.

[9] Chambers, L.E., Altwegg, R., Barbraud, C., Barnard, P., Beaumont, L.J., Crawford, R.J.M., Durant, J.M., Hughes, L., Keatley, M.R., Low, M., Morellato, P.C., Poloczanska, E.S., Ruoppolo, V., Vanstreels, R.E.T., Woehler, E.J., Wolfaardt, A.C. (2013): Phenological changes in the Southern Hemisphere. - PLoS One 8: e75514.

[10] Cleland, E.E., Chuine, I., Menzel, A., Mooney, H.A., Schwartz, M.D. (2007): Shifting plant phenology in response to global change (Review). - Trends in Ecology and Evolution 22 (7):357-365.

[11] Cramer,W., Yohe, G.W., Auffhammer, M., Huggel, C., Molau, U., da Silva Dias, M.A.F., Solow, A., Stone, D.A., Tibig, L. (2014): Detection and attribution of observed impacts. In: Climate Change 2014: Impacts, Adaptation, and Vulnerability. Part A: Global and Sectoral Aspects. Contribution of Working Group II to the Fifth Assessment Report of the Intergovernmental Panel on Climate Change [Field, C.B., V.R. Barros, D.J. Dokken, K.J. Mach, M.D. Mastrandrea, T.E. Bilir, M. Chatterjee, K.L. Ebi, Y.O. Estrada, R.C. Genova, B. Girma, E.S. Kissel, A.N. Levy, S. MacCracken, P.R. Mastrandrea, and L.L.White (eds.)]. Cambridge University Press, Cambridge, United Kingdom and New York, NY, USA, pp. 979-1037.

[12] Demarée, G.R., Rutishauser, T. (2011): From "Periodical Observations" to "Anthochronology" and "Phenology" - the scientific debate between Adolphe Quetelet and Charles Morren on the origin of the word "Phenology". - International Journal of Biometeorology 55:753-761.

[13] Dickinson, J.L., Bonney, R. (2012): Citizen Science: Public participation in environmental research. - Comstock Publishing Associates, Ithaca, NYC, pp 51.

[14] Dose, V., Menzel, A. (2004): Bayesian analysis of climate change impacts in phenology. - Glob. Change Biol. 10:259-272.

[15] Elzinga, J. A., Atlan, A., Biere, A., Gigord, L., Weis, A. E., Bernasconi, G. (2007): Time after time: flowering phenology and biotic interactions (Review). - Trends in Ecology and Evolution 22 (8):432-439.

[16] Estes, J. A., Terborgh, J., Brashares, J. S., Power, M. E., Berger, J., Bond, W. J., Carpenter, S. R., Essington, T. E., Holt, R. D., Jackson, J. B. C., Marquis, R. J., Oksanen, L., Oksanen, T., Paine, R.T., Pikitch, E. K., Ripple, W. J., Sandin, S. A., Scheffer, M., Schoener, T. W., Shurin, J. B., Sinclair, A. R. E., Soulé, M. E., Virtanen, R., Wardle, D. A. (2011): Trophic Downgrading of Planet Earth (Review). - Science 333:301-306.

[17] Fitter, A. H., Fitter, R. S. R. (2002): Rapid changes in flowering time in British plants. Science 296:1689-1691. 
[18] Fitter, A. H., Fitter, R. S. R., Harris, I. T. B., Williamson, M. H. (1995): Relationships between first flowering date and temperature in the flora of a locality in central England. - Functional Ecology 9:55-60.

[19] Haan, C.T. (2002): Statistical methods in Hydrology, second edition: Ames, Iowa, Iowa State University Press.

[20] Holopainen, J., Helama, S., Timonen, M. (2006): Plant phenological data and tree-rings as paleoclimate indicators in south-west Finland since AD 1750. - International Journal of Biometeorology 51:61-72.

[21] Hurrell, J. W., Kushnir, Y., Ottersen, G., Visbeck, M. (2003): An Overview of the North Atlantic Oscillation. - The North Atlantic Oscillation: Climate Significance and Environmental Impact, Geophysical Monograph Series 134:1-35

[22] Ge, Q., Wang, H., Rutishauser, T., Dai, J. (2015): Phenological response to climate change in China: a meta-analysis. - Global Change Biology. 21(1):265-274.

[23] Gordo, O., Sanz, J.J. (2010): Impact of climate change on plant phenology in Mediterranean ecosystems. - Global Change Biology 16 (3):1082-1106.

[24] Jones, P.D., Jónsson, T., Wheeler, D. (1997): Extension to the North Atlantic Oscillation using early instrumental pressure observations from Gibraltar and South-West Iceland. Int. J. Climatol. 17:1433-1450.

[25] Kiss, A., Wilson, R., Bariska, I. (2010): An experimental 392-year documentary-based multi-proxy (vine and grain) reconstruction of May-July temperatures for Köszeg, WestHungary. - Int. J. Biometeorology 55 (4):595-611.

[26] Lavoie, C., Lachance D. (2006): A new herbarium-based method for reconstructing the phenology of plant species across large areas. - American Journal of Botany 93 (4):512516.

[27] Lieth, H. (ed.) (1974): Phenology and seasonality modeling. Ecological studies 8, Springer V., 444 pp.

[28] Lima A.L.A., Rodal M.J.N. (2010): Phenology and wood density of plants growing in the semi-arid region of northeastern Brazil. - Journal of Arid Environments 74 (11):13631373.

[29] Mandl, É. (2009): Az Észak-Atlanti Oszcilláció hatása a Kárpát-medence térségének éghajlatára (B.Sc. thesis). Budapest, 53 pp. (in Hungarian)

[30] Menzel, A. (2002): Phenology: Its importance to the global change community (An Editorial Comment). - Climatic Change 54:379-385.

[31] Menzel, A. (2003): Plant phenological anomalies in Germany and their relation to air temperature and NAO. - Climatic Change 57:243-263.

[32] Menzel, A., Sparks, T.H., Estrella, N., Koch, E., Aasa, A., Ahas, R., Alm-Kubler, K., Bissolli, P., Braslavska, O., Briede, A., Chmielewski, F.M., Crepinsek, Z., Curnel, Y., Dahla, A., Defila, C., Donnelly, A., Filella, Y., Jatcza, K., Mage, F., Mestre, A., Nordli, O., Penuelas, J., Pirinen, P., Remisova, V., Scheifinger, H., Striz, M., Susnik, A., van Vliet, A.J.H., Wielgolaski, F.E., Zach, S., Zust, A. (2006): European phenological response to climate change matches the warming pattern. - Global Change Biology 12:1969-1976.

[33] Miller-Rushing, A., Primack, R.B. (2008): Global warming and flowering times in Thoreau's Concord: a community perspective. - Ecology 89 (2):332-341.

[34] Miller-Rushing, A., Inouye, D. W., Primack, R.B. (2008): How well do first flowering dates measure plant responses to climate change? The effects of population size and sampling frequency. - Journal of Ecology 96:1289-1296.

[35] Osborn, T.J. (2006): Recent variations in the winter North Atlantic Oscillation. Weather 61:353-355.

[36] Ovaskainen, O., Skorokhodova, S., Yakovleva, M., Sukhov, A., Kutenkov, A., Kutenkovab, N., Shcherbakovb, A., Meykea, E., del Mar Delgado, M. (2013): Community-level phenological response to climate change. - Proceedings of the National Academy of Sciences of the United States of America 110 (33):13434-13439. 
[37] Parmesan, C., Yohe, G. (2003): A globally coherent fingerprint of climate change impacts across natural systems. - Nature 421:37-42.

[38] Pau, S., Wolkovich, E.M., Cook, B.I., Davies, T.J., Kraft, N.J.B., Bolmgren, K., Betancourt, J.L., Cleland, E.E. (2011): Predicting phenology by integrating ecology, evolution and climate science (Review). - Global Change Biology 17 (12):3633-3643.

[39] Pongrácz, R., Bartholy, J., Miklós, E. (2011): Analysis of projected climate change for Hungary using ENSEMBLES simulations. - Applied Ecology and Environmental Research 9:387-398.

[40] Roberts, A.M.I. (2010): Smoothing Methods. In Phenological Research - Methods for Environmental and Climate Analysis. Springer, London, $521 \mathrm{pp}$.

[41] Root, T.L., Price, J.T., Hall, K.R., Schneider, S.H., Rosenzweig, C., Pounds, J.A. (2003): Fingerprints of global warming on wild animals and plants. - Nature 421:57-60.

[42] Root, T.L., MacMynowski, D.P., Mastrandrea, M.D., Schneider, S.H. (2005): Humanmodified temperatures induce species changes: Joint attribution. - Proceedings of the National Academy of Sciences 102 (21):7465-7469.

[43] Rutishauser, T., Luterbacher, J., Jeanneret, F., Pfister, C., Wanner, H. (2007): A phenology-based reconstruction of interannual changes in past spring seasons. - Journal of Geophysical Research 112: G04016.

[44] Rutishauser, T., Schleip, C., Sparks, T.H., Nordli, Ø., Menzel, A., Wanner, H., Jeanneret, F., Luterbacher, J. (2009): Temperature sensitivity of Swiss and British plant phenology from 1753 to 1958. - Clim Res 39:179-190.

[45] Schleip, C., Menzel, A., Estrella, N., Dose, V. (2006): The use of Bayesian analysis to detect recent changes in phenological events throughout the year. - Agric. For. Meteorol. 141:179-191.

[46] Schleip, C., Rais, A., Menzel, A. (2009): Bayesian analysis of temperature sensitivity of plant phenology in Germany. - Agricultural and Forest Meteorology 149 (10):16991708.

[47] Schwartz, M.D., Ahas, R., Aasa, A., 2006: Onset of spring starting earlier across the Northern Hemisphere. - Global Change Biology 12:343-351.

[48] Schwartz, M.D. (2013): Phenology: An Integrative Environmental Science. Springer Science \& Business Media, ISBN: 9400769253,610 pp.

[49] Sparks, T.H., Jeffree, E.P., Jeffree, C.E. (2000): An examination of the relationship between flowering times and temperature at the national scale using long-term phenological records from the UK. - International Journal of Biometeorology 44:82-87.

[50] StatSoft, Inc. (2003): Statistica 6.1 - STATISTICA (data analysis software system)

[51] Stenseth, N.C., Ottersen, G., Hurrell, J.W., Mysterud, A., Lima, M., Chan, K.S., Yoccoz, N.G., Adlandsvik, B. (2003): Studying climate effects on ecology through the use of climate indices: the North Atlantic Oscillation, El Nino Southern Oscillation and beyond (Review paper). - Proc. R. Soc. Lond. Biol. Sci. 270:2087-2096.

[52] Szabó, B., Vincze, E., Czùcz, B. (2016): Flowering-phenological changes in relation to climate change in Hungary. - International Journal of Biometeorology. DOI 10.1007/s00484-015-1128-1.

[53] Szalai, S., Bella, Sz., Németh, Á., Dunay, S. (2008): History of Hungarian phenological observations. - In: Nekovár, J., Koch, E., Kubin, E., et al. (eds.) COST Action 725. The history and current status of plant phenology in Europe. Pp. 88-93.

[54] Trigo, R.M., Osborn, T.J. and Corte-Real, J.M. (2002): The North Atlantic Oscillation influence on Europe: climate impacts and associated physical mechanisms. - Climate Research 20:9-17.

[55] Varga, Z., Varga-Haszonits, Z., Enzsölné Gerencsér, E., Milics, G. (2009a): A kislevelü hárs (Tilia cordata L.) fejlődésének bioklimatológiai elemzése. - Acta Agronomica Óváriensis 51:21-38. (in Hungarian) 
[56] Varga, Z., Varga-Haszonits, Z., Enzsölné Gerencsér, E., Lantos, Zs., Milics, G. (2009b): A fekete bodza (Sambucus nigra L.) fejlődésének bioklimatológiai elemzése. Kertgazdaság 41:66- 79. (in Hungarian)

[57] Varga, Z., Varga-Haszonits, Z., Enzsölné Gerencsér, E., Lantos, Zs., Milics, G. (2010): A májusi orgona (Syringa vulgaris L.) fejlődésének fenológiai és bioklimatológiai elemzése. „Klíma-21” Füzetek - Klímaváltozás-hatások-válaszok 60, 22-35. (in Hungarian)

[58] Walkovszky, A. (1998): Changes in phenology of the locust tree (Robinia pseudoacacia L.) in Hungary. - International Journal of Biometeorology 41:155-160.

[59] Walther, G.R., Post, E., Convey, P., Menzel, A., Parmesan, C., Beebee, T.J.C., Fromentin, J.M., Hoegh-Guldberg, O.H., Bairlein, F. (2002): Ecological responses to recent climate change. - Nature 416:389-395.

[60] Wang, H., Ge, Q., Dai, J., Tao Z. (2015): Geographical pattern in first bloom variability and its relation to temperature sensitivity in the USA and China. - International Journal of Biometeorology 59:961-969. 


\section{Appendix}

Table A. Four examples (Sp-1: Tussilago farfara, Sp-2: Scilla bifolia, Sp-4: Caltha palustris, and Sp-5: Salix fragilis) for finding the period of most effective temperature $\left(T_{e f f}\right)$ of flowering onsets using serial cross correlation functions $(C C F)$ and moving window technique with different number (1, 2, 3 and 4$)$ of months. Legend: bold numbers: significant correlation coefficient value $(r 0)(p<0.05)$; pale yellow cell: the highest correlation coefficient in the column; orange cell: the highest correlation coefficient for the plant, so it reflects to the effective temperature period; blue cell: significant influence of the previous year. To determine the $T_{\text {eff }}$ period the moving window method was applied on monthly data from the previous June until the July of the actual year regarding the occurrence of phenophase.

\begin{tabular}{|c|c|c|c|c|c|c|c|c|c|c|c|c|c|c|c|}
\hline $\begin{array}{l}\text { 1-monthly } \\
\text { mean }\end{array}$ & ro & $\begin{array}{c}\text { 2-monthly } \\
\text { mean }\end{array}$ & ro & $\begin{array}{c}\text { 3-monthly } \\
\text { mean }\end{array}$ & ro & 4-monthly mean & ro & 1-monthly mean & ro & $\begin{array}{c}\text { 2-monthly } \\
\text { mean }\end{array}$ & ro & $\begin{array}{c}\text { 3-monthly } \\
\text { mean }\end{array}$ & ro & $\begin{array}{l}\text { 4-monthly } \\
\text { mean }\end{array}$ & ro \\
\hline JUN & -0.178 & $\overline{J J}$ & -0.0173 & JJA & 0.0116 & JJAS & -0.0031 & JUN & 0.1106 & JJ & 0.1557 & JJA & 0.1721 & JJAS & 0.1883 \\
\hline JUL & 0.1745 & JA & 0.06 & JAS & 0.0278 & JASO & 0.0324 & JUL & \begin{tabular}{|l|l|l|}
0.112 \\
\end{tabular} & JA & 0.1833 & JAS & 0.2026 & JASO & 0.2348 \\
\hline AUG & 0.1921 & AS & 0.0127 & ASO & 0.0227 & ASON & -0.0387 & AUG & 0.1118 & AS & 0.2151 & ASO & 0.2576 & ASON & 0.2531 \\
\hline SEP & -0.0721 & SO & -0.0097 & SON & -0.0928 & SOND & -0.1858 & SEP & 0.1121 & SO & 0.281 & SON & 0.2608 & SOND & 0.2939 \\
\hline OCT & 0.0606 & ON & -0.0966 & OND & -0.2101 & ONDJ & -0.3647 & OCT & 0.1132 & ON & 0.2214 & OND & 0.2588 & ONDJ & 0.2155 \\
\hline NOV & -0.1765 & ND & -0.2818 & NDJ & -0.4143 & NDJF & -0.6294 & NOV & 0.111 & ND & 0.1564 & NDJ & 0.1192 & NDJF & -0.0947 \\
\hline DEC & -0.2064 & DJ & -0.3595 & DJF & -0.5935 & DJFM & -0.6507 & DEC & 0.1129 & DJ & 0.0888 & DJF & -0.1307 & DJFM & -0.3203 \\
\hline JAN & -0.3561 & JF & -0.6427 & JFM & -0.6642 & JFMA & -0.6328 & JAN & 0.0345 & JF & -0.2286 & JFM & -0.444 & JFMA & -0.5132 \\
\hline FEB & -0.6754 & FM & -0.6232 & FMA & -0.5752 & FMAM & -0.544 & FEB & \begin{tabular}{|l|}
-0.4133 \\
\end{tabular} & FM & -0.6196 & FMA & -0.6738 & FMAM & -0.5619 \\
\hline MAR & -0.2894 & MA & -0.2661 & MAM & -0.2205 & MAMJ & -0.2552 & MAR & -0.6243 & MA & -0.6613 & MAM & -0.4567 & MAMJ & -0.4849 \\
\hline APR & -0.112 & AM & -0.0632 & AMJ & -0.1032 & AMJJ & -0.0475 & APR & -0.3992 & AM & -0.1079 & AMJ & -0.1243 & AMJJ & -0.0505 \\
\hline MAY & 0.0244 & MJ & -0.0265 & MJJ & 0.0312 & - & - & MAY & 0.2639 & MJ & 0.2211 & MJJ & 0.2579 & \multirow{3}{*}{\multicolumn{2}{|c|}{ Caltha palustris (Sp-4) }} \\
\hline JUN & -0.0735 & $\mathrm{JJ}$ & 0.0164 & - & - & \multirow{2}{*}{\multicolumn{2}{|c|}{$\begin{array}{c}\text { Tussilago farfara } \\
\text { (Sp-1) }\end{array}$}} & JUN & -0.0269 & $\mathrm{JJ}$ & 0.0798 & - & - & & \\
\hline JUL & 0.1144 & - & - & - & - & & & JUL & 0.155 & - & - & - & - & & \\
\hline $\begin{array}{l}\text { 1-monthly } \\
\text { mean }\end{array}$ & ro & $\begin{array}{c}\text { 2-monthly } \\
\text { mean }\end{array}$ & ro & $\begin{array}{c}\text { 3-monthly } \\
\text { mean }\end{array}$ & ro & 4-monthly mean & ro & 1-monthly mean & ro & $\begin{array}{c}\text { 2-monthly } \\
\text { mean }\end{array}$ & ro & $\begin{array}{c}\text { 3-monthly } \\
\text { mean }\end{array}$ & ro & $\begin{array}{l}\text { 4-monthly } \\
\text { mean }\end{array}$ & ro \\
\hline JUN & -0.0049 & $\mathrm{JJ}$ & 0.1133 & JJA & 0.1764 & JJAS & 0.1664 & JUN & 0.1858 & $\mathrm{JJ}$ & 0.1836 & JJA & 0.1772 & JJAS & 0.1957 \\
\hline JUL & 0.0139 & $\mathrm{JA}$ & 0.2797 & JAS & 0.2477 & JASO & 0.3351 & JUL & 0.1862 & $J A$ & 0.1759 & JAS & 0.2016 & JASO & 0.2365 \\
\hline AUG & 0.0108 & AS & 0.1598 & ASO & 0.2906 & ASON & 0.257 & AUG & 0.1856 & AS & 0.2001 & ASO & 0.2492 & ASON & 0.2581 \\
\hline SEP & 0.0037 & SO & 0.249 & SON & 0.2191 & SOND & 0.1089 & SEP & 0.1872 & SO & 0.2949 & SON & 0.2891 & SOND & 0.3604 \\
\hline OCT & 0.0218 & ON & 0.2137 & OND & 0.0987 & ONDJ & 0.01 & OCT & 0.1886 & ON & \begin{tabular}{|l|l|}
0.2524 \\
\end{tabular} & OND & 0.3365 & ONDJ & 0.3058 \\
\hline NOV & 0.009 & $\mathrm{ND}$ & -0.0138 & NDJ & -0.0819 & NDJF & -0.2989 & NOV & \begin{tabular}{|l|l|}
0.1874 \\
\end{tabular} & ND & 0.2467 & NDJ & 0.2134 & NDJF & -0.0075 \\
\hline DEC & -0.0114 & DJ & -0.131 & DJF & -0.3497 & DJFM & -0.507 & DEC & \begin{tabular}{|l|l|}
0.1908 \\
\end{tabular} & DJ & 0.1723 & DJF & -0.0532 & DJFM & -0.2706 \\
\hline JAN & -0.1174 & JF & -0.3915 & JFM & -0.554 & JFMA & -0.5367 & JAN & 0.0983 & JF & -0.1666 & JFM & -0.4273 & JFMA & -0.5521 \\
\hline FEB & -0.5182 & FM & -0.6544 & FMA & -0.6068 & FMAM & -0.5077 & FEB & \begin{tabular}{|l}
-0.3795 \\
\end{tabular} & FM & -0.6448 & FMA & -0.7637 & FMAM & -0.6659 \\
\hline MAR & -0.5514 & MA & -0.4594 & MAM & -0.2922 & MAMJ & -0.2591 & MAR & \begin{tabular}{|l|l|}
-0.7155 \\
\end{tabular} & MA & -0.8321 & MAM & -0.6297 & MAMJ & -0.6334 \\
\hline APR & -0.1191 & AM & 0.0772 & AMJ & 0.1447 & AMJJ & 0.1519 & APR & \begin{tabular}{|l|l}
-0.5927 \\
\end{tabular} & AM & -0.2848 & AMJ & -0.2582 & AMJJ & -0.2424 \\
\hline MAY & 0.2363 & MJ & 0.3014 & MJJ & 0.2867 & - & - & MAY & 0.209 & MJ & 0.2334 & MJJ & 0.1717 & \multirow{3}{*}{\multicolumn{2}{|c|}{$\begin{array}{l}\text { Salix fragilis } \\
\quad(\mathrm{Sp}-5)\end{array}$}} \\
\hline JUN & 0.1309 & JJ & 0.1503 & - & - & \multirow{2}{*}{\multicolumn{2}{|c|}{ Scilla bifolia (Sp-2) }} & JUN & 0.066 & JJ & 0.0179 & - & - & & \\
\hline JUL & 0.0724 & - & - & - & - & & & JUL & -0.0521 & - & - & - & - & & \\
\hline
\end{tabular}

APPLIED ECOLOGY AND ENVIRONMENTAL RESEARCH 14(2): 213-233

http://www.aloki.hu • ISSN 15891623 (Print) • ISSN 17850037 (Online)

DOI: 10.15666/aeer/1402_213233

(c) 2016, ALÖKI Kft., Budapest, Hungary 